object. The camera can be driven at speeds varying from 20 to 120 frames a second, while a single or twin film can be used. At these low rates the camera can be started or stopped practically instantaneously without loss of film, and one can expose either $\mathrm{l} \mathrm{ft}$. or $100 \mathrm{ft}$.
The apparatus is somewhat cumbersome, since the are and high-speed disc must be on separate stands or tables from the camera and microscope, while in high-power work the camera itself with its motor must be insulated from the microscope, otherwise vibration will cause difficulties.

\title{
International Congress for Scientific Management
}

$\mathrm{T}^{\mathrm{H}}$ HE International Congress for Scientific Manage. ment to be held in London on July 15 and subsequent dates is the sixth of a series which have been held in various European capitals since 1924. The hosts of the Conference are a Council-nominated by a number of societies interested in one phase or other of the management movement, and the technical societies-which has appointed an executive committee composed of outstanding industrial leaders and others with Sir George Beharrell as chairman. The patron is H.R.H. The Prince of Wales. The organisation is in the hands of committees having as chairmen, Dr. E. F. Armstrong, Sir Henry Fowler, Mr. G. R. Freeman, Sir George Courthope, Prof. Winifred Cullis. The genesis of the invitation is the desire both to entertain the delegates in England, to show that Britain has a factory and business organisation fully up to the most modern practice, and to arouse public interest in general in the subject of scientific management.

The work of the Congress is divided into six sections each of which will hold four technical sessions. The sections will deal with development, distribution, educational and training, manufacturing, agricultural and domestic management respectively. At each session, papers falling under a specific heading will be discussed. The papers, of which there are two hundred, in six distinct volumes, are already in type and have been circulated to members: each paper has a summary in three languages. The papers for each session have been summarised by an expert rapporteur, which summary alone will be read, leaving the session available for discussions which are to be the main feature of the meeting. Presidents of eminence-in all twenty-four-have been obtained for each session.

The Conference will be opened at noon on July 15 by H.R.H. The Prince of Wales, who is taking a keen interest in it and is expected to speak at some length on particular phases of the subject.

The subject chosen for the first plenary session is the topical one of management problems arising from Government intervention, which is expected to give rise to an illuminating discussion.

The second plenary session will be devoted to consideration of the simplification of data, the place of statistics and the standardisation of terms.

A large number of visits has been arranged to factories and to places of interest for members of the agricultural and domestic science sections.

At the end of the Congress, tours have been arranged in special trains with sleeping cars to enable the overseas visitors to combine the inspection of some of our most famed. scenery with visits to some highly organised factories, chosen so as each to illustrate a different phase of the management problem. The social side of the Congress has not been neglected and every opportunity will be given for members to fraternise.

Many of the papers are of outstanding interest and make important contributions to the development of management regarded as an exact science; the authors of the British papers were invited to contribute them by the organising committee as representing the best experience in the particular phases. The information accumulated in the volumes is such that no industrial library can afford to be without them.

It is anticipated that the Congress will have a large, if not a record, membership, but its arrangements have been made as far as possible sufficiently elastic to allow for expansion. There are few in business or wishing to attain managerial rank who are unlikely to profit by attending its deliberations: moreover, every support is deserved by the organisers, who are working on a purely voluntary basis with the sole object of giving testimony to the up-to-date state of British business organisation in every phase of activity.

Intending members should apply immediately to Mr. Harry Ward at 21 Tothill Street, Westminster, S.W.1, so that they may receive the Congress papers in ample time to give them the necessary study.

\section{Fuel Research in Great Britain}

$\mathrm{T}$ HE Fuel Research Station at East Greenwich was open for inspection on June 4, and about 250 guests were received by Sir Harold Hartley, chairman of the Fuel Research Board, and Dr. F. S. Sinnatt, Director of Fuel Research. The whole of the plant was on view, and the work in progress was explained and demonstrated.

Particular interest was taken in the new semi-commercial scale plant for the hydrogenation-cracking of tar to motor spirit. This plant commenced working on March 1, and was on view for the first time. It is designed to deal with 300 gallons of tar or creosote a day. One passage through the plant converts about half the tar to motor spirit, and by recirculating the residue the whole of the tar can be converted, yielding an equal volume of spirit. Demonstrations were given of a new plant for the dry cleaning of coal, while a washery table was preparing 'ultra clean' coal containing less than $1 \frac{1}{2}$ per cent of ash, from a commercial coal containing about 5 per cent. The coal survey that is being carried on throughout the coal fields of Great Britain has shown that large quantities of 'ultra clean' coal of various types can readily be prepared if required for special purposes.

The pulverised fuel burners designed at the Fuel Research Station, and now in commercial use, were 
shown working in both Lancashire and water tube boilers. A method of dividing a stream of air-borne coal into two equal streams was illustrated; owing to the unequal distribution of the coal over the crosssection of the pipe when pulverised coal is carried in a stream of air, this equal division has presented difficulties. An ingenious device for estimating the rate of settlement of a suspension of a solid in a viscous liquid was on view. The tube containing the suspension forms part of a pendulum, the change of the period of swing of which is a measure of the rate at which the centre of gravity of the system moves downwards. This apparatus was designed for investigations into the stability of suspensions of coal in oil, but may have other applications.

The experiments in the full-scale horizontal gas retorts, showing the advantages of introducing steam during the last portion of the carbonising period, were of special interest to gas engineers.

\section{Fauna of Indian Salt Lakes}

$\mathrm{I}^{\mathrm{I}}$ UT.-COL. R. B. SEYMOUR SEWELL has made an interesting study of the fauna of the salt lakes of Calcutta (Rec. Ind. Mus., 36, Part 1. 1934). Recent changes in the general character of some of the rivers in Lower Bengal have had a profound effect on these salt lakes and their associated streams, indirectly influencing the general character of the fauna of certain areas, silting in the rivers and canals due to various causes being the main factor in these changes.

The chief zoological interest in this brackish-water area lies in the fact that it forms one of the main highways by which marine organisms gradually establish themselves in fresh-water. In the neigh. bourhood of the large river estuaries there is a very great amount of available food, both organic and inorganic, and there is a considerable lowering of the salinity in the surface water. The coastal species must be able to withstand a wide variation of salinity, and a further step from brackish- to fresh-water would not be difficult.

The region was almost certainly part of the Bay of Bengal, and with a gradual extension of the delta seawards the water of the rivers and lakes became less salt, but extremely slowly. Both marine forms from the coastal waters and fresh-water species from the rivers would be carried into the salt lakes. There seem to be few instances of a definite attempt at migration upstream from the sea to the fresh-water areas above the influence of the tide.

Although other groups are mentioned and to a certain extent listed, the copepods are studied in the greatest detail. There are true fresh-water forms in the Hooghly River, and in the salt lake with the pools and canals there are normal brackish-water forms; associated with the latter we may get definitely marine forms, a gradual change from freshwater to salt-water species showing in the plankton from the fresh-water of the river system towards the sea.

With regard to the widely distributed Pseudodiaptomus, it is a question whether migration has been from the sea into fresh-water or from freshwater to the sea, or from brackish-water into both regions. The author is of the opinion that it is of marine origin, and that there has been, and still is, a tendency towards migration into brackish- and on into fresh-water.

\section{University and Educational Intelligence}

CAmbridge.-Mr. G. H. A. Wilson, Master of Clare College and formerly M.P. for the University, has been elected Vice-Chancellor for the academical year 1935-36.

Dr. W. H. Thorpe, of Jesus College, has been reappointed University lecturer in entomology. Dr. D. H. Barron has been appointed University demonstrator in anatomy.

Miss Dorothy Hill, of Newnham College, has been awarded a Senior Studentship by the Royal Commissioners for the Exhibition of 1851.

OxFORD.-Dr. N. V. Sidgwick has been granted the title of professor during the tenure of his readership in chemistry.

Dr. A. H. Gardiner, vice-president of the Egypt Exploration Society and research professor of Egyptology in the University of Chicago, has been elected honorary fellow of the Queen's College.

IN order to encourage research on eugenic problems, and on the genetical and statistical methods needed, if they are to be profitably attacked, the Eugenics Society has decided to provide the funds for a research studentship of $£ 250$ a year, tenable at any of a number of suitable research departments in the United Kingdom. The studentships will bear the name of Leonard Darwin, honorary president of the Society. To make the awards and administer the studentships, an independent committee has been set up with the co-operation of the Royal Society, the Royal Society of Edinburgh, and the Royal Statistical Society. The studentships will be renewable for a second year.

The Social Studies final report of the American Historical Association (Scribner, 1934, pp. 168, 1.25 dollars) has become one of the chief subjects of educational discussion in America. Dealing as it does with some of the most vital issues of contemporary social life in that country and being, according to one critic, a "daringly realistic" indictment of the present social order, it has, naturally, come in for a good deal of abuse. In School and Society of March 30 appears an address by Prof. Jesse H. Newlon to the American Educational Research Association, in which some of the attacks on it are answered. Among these are complaints of paying lip-service to democratic ideals while knifing them in the back by enlarging on trends towards collectivism, of countenancing the indoctrination of students with subversive ideas, of decrying objective tests and the scientific method generally, of needlessly disparaging existing methods of instruction in teacher-training institutions as mechanical and sterile, of irrelevant eriticism of systems of control and administration of schools. The answers throw much interesting light on current educational practices. Prof. Newlon holds that the scientific method has become a sort of fetisheducational research being concentrated on it as a chief objective in the delusive belief that it can not merely illuminate, but also provide qualitative solutions of problems of educational policy. Summing up the significance of the report, it dares, he says, to make a social analysis and, in harmony therewith, to recommend policies for making education a more effective instrument for social reconstruction. 